\title{
Research Paper Price dynamics of domestic and international maize markets: A vector error correction mechanism (VECM) approach
}

\section{R. PANGAYAR SELVI, S. MURALI GOPAL AND B. SWAMINATHAN}

See end of the paper for authors' affiliations

Correspondence to : R. PANGAYAR SELVI Department of Physical Sciences and IT, Agricultural Engineering College and Research Institute, Tamil Nadu Agricultural University, COIMBATORE (T.N.) INDIA Email:pangai@rediffmail. com

Paper History :

Received : 04.07.2014;

Revised : 01.08.2014;

Accepted: 15.08 .2014
ABSTRACT: Market integration in agricultural commodities is vital for both developed and developing countries alike. If prices are not perfectly transmitted, then it may lead to distortions in production and distribution. The strength of interdependence among markets and the speed in which the changes are passed through determine the degree of integration and the global efficiency of markets. This study examines the long-run and short-run integration of domestic and international maize markets using Co-integration approach within the framework of Vector Error Correction Mechanism (VECM). A sample of five domestic maize markets comprising two from the traditional maize growing states of Madhya Pradesh, and Rajasthan and three from the non-traditional Andhra Pradesh, Karnataka, and Tamil Nadu were selected along with two international maize markets comprising from United States and Argentina. Analysis was carried out using the monthly price data between January 2003 and Dec 2013. Findings revealed that the prices became stationary only upon first differencing. The existence of integration was confirmed among markets implying that there is price transmission. The estimated error coefficients revealed that in Tamil Nadu market disequilibrium got corrected within a month by changes in its own prices with speed of convergence at 28 per cent in the long-run path. But for other markets the speed of convergence ranged from 20 per cent to 57 per cent for short-run price movements to become stable along long-run equilibrium path in one or two-month lagged period.

KEY WORDS : Stationarity, Market Integration, Co-integration, Short-run disequilibrium

HOW TO CITE THIS PAPER : Selvi, R. Pansayar, Gopal, S. Murali and Swaminathan, B. (2014). Price dynamics of domestic and international maize markets: A vector error correction mechanism (VECM) approach. Internat. Res. J. Agric. Eco. \& Stat., 5 (2) : 272-277. 